\title{
Effects of Pressure on the Micellization of Tetradecane-1-sulfonates with Divalent Cation of Separate Electric Charges as Counterion
}

\author{
Yoshikiyo MoroI*1, Satoshi KAWASAKI*2, Yoshiaki KAI*2, \\ Yoshio Murata*1, and Mitsuru TANAKA*2 \\ *1 Department of Chemistry, Faculty of Science, Kyushu University \\ (Hakozaki 6-10-1, Higashi-ku, Fukuoka-shi, †812-81) \\ *2 Department of Chemistry, Faculty of Science, Fukuoka University \\ (Nanakuma 8-19-1, Jyonan-ku, Fukuoka-shi, =814-80)
}

\begin{abstract}
The effects of pressure on the solution properites of tetradecane-1-sulfonates with divalent cation of separate electric charges as counterion $\left[1,1^{\prime}-(1, \omega\right.$-alkanediyl $)$ bispyridinium tetradecane-1sulfonate]

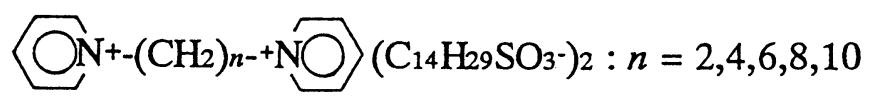

were examined at $40^{\circ} \mathrm{C}$ by the critical micelle concentration $(\mathrm{cmc})$ and by the aqueous solubility. Specific conductivity of the surfactants below the cme was found to increase monotonously with pressure. Longchain surfactant anions would thus appear to associate with the divalent cations below the $\mathrm{cmc}$, the extent of which decreasing with increasing pressure. The cmc of all surfactants was found to have a maximum around $140 \mathrm{MP}$ as conventional ionic surfactants. The volume change on micellization, $\Delta V_{\mathrm{m}}$, was determined based on the pressure dependence of $\mathrm{cmc}$, and $\Delta V_{\mathrm{m}}$ was observed to decrease more rapidly with pressure for shorter charge separation of the counterions. Dynamic light scattering was measured for micellar solutions, and the results indicated the hydrodynamic radius of micelles to be considerably controlled by divalent cationic counterions of increasing charge separation.
\end{abstract}

Key words : critical micelle concentration $(\mathrm{cmc})$, pressure effect on micellization, divalent counterion of separate electric charge, dynamic radius of micelle.

\section{Introduction}

As is well known, solution properties of ionic surfactants are governed much by counterion. In recent years, counterions studied with interest have shifted from metallic and halogen ions to organic one ${ }^{1) \sim 3}$, and the effect of hydrophobicity of counterions on micelle formation has been examined. In our previous studies on the $1,1^{\prime}-(1, \omega$-alkanediyl $)$ bispyridinium alkane-1-sulfonates, the following conclusions were drawn : 1$)$ as for $1,1^{\prime}-(1, \omega$-alkanediyl $)$ bispyridinium tetradecane-1-sulfonates, the alkanediyl groups penetrate hydrophobic micellar interior made of tetradecane-1-sulfonates, when the separation between two cationic charges becomes more than 6 by $\mathrm{CH}_{2}$ unit $^{4)}$, 2) as for the above same surfactants, the micellar aggregation number goes through a minimum around 10 by the same unit ${ }^{5}$, 3) as for $1,1^{\prime}-(1, \omega$-tetradecanediyl) bispyridinium alkane-1-sulfonates, the cmc steeply decreases and the micelle aggregation number increases from the sulfonate anion with carbon atoms

Corresponding author : Yoshikiyo MOROI 
more than $6^{6)}$, and 4) $\mathrm{cmc}$ of the surfactants has a maximum around $130 \mathrm{MP}$ as conventional surfactants and hydrodynamic radius of micelles is controlled mainly by bolaform-type counterion $^{7)}$. In the above first three studies, the temperature effect was carefully examined, but the effect of pressure which is another important thermodynamic intensive variable for estimation of a volume change of chemical processes has not been examined yet. There have appeared many papers on the pressure effect on $\mathrm{cmc}$ and on aqueous solubility of conventional ionic surfactants ${ }^{8) ~ 10)}$, and it was found that $\mathrm{cmc}$ went through a maximum around $150 \mathrm{MP}$ and that a monomeric solubility decreased with increasing pressure. The surfactants used in this study are those with a new-type counterion, and therefore, an examination of pressure effect on the present surfactants should be quite informative for better understanding of micelle formation.

\section{Experimental}

\subsection{Materials}

One of the mother materials of the present surfactants, 1,1'-(1, $\omega$-alkanediyl $)$ bispyridinium dibromide $\left(\mathrm{C}_{n} \mathrm{BPBr}_{2}\right)$, is a kind gift from the former Prof. Kuwamura's laboratory of Gumma University, and the preparation was given in the previous paper $\left.{ }^{4}\right) \cdot 1,1^{\prime}-(1, \omega$-alkanediyl) bispyridinium tetradecane-1-sulfonate $\left\{\mathrm{C}_{n} \mathrm{BP}\left(\mathrm{C}_{14}\right)_{2}\right]$ was prepared by mixing an equivalent amount of $\mathrm{C}_{n} \mathrm{BPBr}_{2}$ and $\mathrm{C}_{14} \mathrm{H}_{29} \mathrm{SO}_{3} \mathrm{Ag}$ in aqueous solution, and the $\mathrm{AgBr}$ precipitate formed was separated by centrifugation. Water of the supernatant was removed by freeze-drying. $\mathrm{C}_{n} \mathrm{BP}\left(\mathrm{C}_{14}\right)_{2}$ thus obtained was purified by repeated recrystallizations from acetone solution. The purity was checked by elemental analysis, and the observed and calculated values were in satisfactory agreement within experimental errors for $\mathrm{C}, \mathrm{H}$, and $\mathrm{N}$ atoms.

\subsection{Electric Conductivity under High Pressure}

The conductivity cell with platinized platinum electrode was hand-made of an injection tube. Pressure on the solution inside the tube was applied by an inner syringe of the tube through a pressure medium. The pressure vessel and pump were from Hikari Kiki Co. Ltd. and illustrated before ${ }^{11)}$. The pressure vessel had three sapphire windows for its inside to be seen from outside, and ligroin was used as a pressure medium. The specific conductivity of surfactant solution was determined by Yanako MY-8 from Yanagimoto MFG. Co. Ltd., where the cell constant was evaluated by a standard aqueous solution for potassium chloride.

\subsection{Hydrodynamic Radius of Micelles}

Dynamic light scattering measurement was made at $40.0^{\circ} \mathrm{C}$ by Super Dynamic Light Scattering Photometer, Ohtsuka Electric Co. Ltd. DLS $7000 \mathrm{FU}$ in order to determine a mean hydrodynamic radius of the micelles, where the laser light of wave-length $488 \mathrm{~nm}$ was used. Filtration of the solutions was carried out with MILLEX-VV of pore-size $0.2 \mu \mathrm{m}$.

\section{Results and Discussion}

For better understanding of the solution properties of such complicated surfactants as the present case, firstly the dependence of electric conductivity of $\mathrm{C}_{2} \mathrm{BP}\left(\mathrm{C}_{14}\right)_{2}$ solutions on pressure are given for typical four concentrations; two each below and above the cmc (Fig. 1). The specific conductivity of conventional ionic surfactants like sodium decylsulfonate $\left(\mathrm{NaC}_{10}\right)$ monotonously decreases below the cmc with pressure ${ }^{7)}$. This is because viscosity of water as the solvent increases, on the contrary, with increasing pressure above $30^{\circ} \mathrm{C}^{12)}$ and because the conductivity is inversely proportional to solvent viscosity. On the other hand, the conductivity shows a maximum around $150 \mathrm{MP}$ in the solutions above cmc. The maximum has been explained by increasing dissociation of micelles with pressure up to around $150 \mathrm{MP}$ and by promotion of micellization above the pressure. This is well known as the presence of cmc 


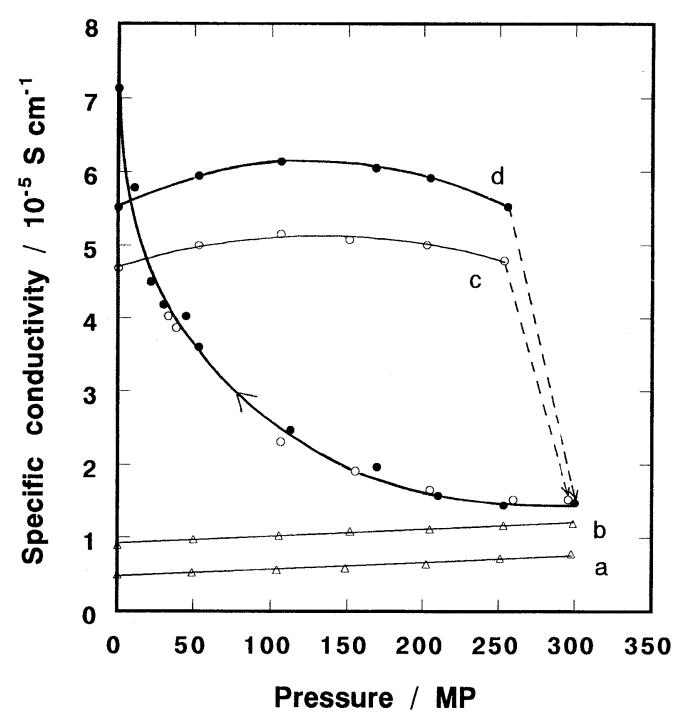

Fig. 1 Pressure Dependence of Specific Conductivity of $\mathrm{C}_{2} \mathrm{BP}\left(\mathrm{C}_{14}\right)_{2}$ Solutions Below and Above the $\mathrm{cmc}$ at $40.0^{\circ} \mathrm{C}$ : a $0.03, \mathrm{~b} 0.09$, c $0.30, \mathrm{~d} 0.94 \mathrm{mmol} \mathrm{kg}^{-1}$.

maximum around the pressure ${ }^{10)}$. This was also the case for sodium dodecylsulfate ${ }^{9)}$, although the results are not shown here. Pressure effect on the specific conductance was well discussed in the preceding paper ${ }^{7}$.

At a certain concentration and a certain pressure above the $\mathrm{cmc}$, the specific conductivity (k) suddenly jumped down accompanied by an appearance of the precipitation of the surfactant in solution. This jump results from a decrease in solubility of surfactant with increasing pressure. The monomeric solubility was carefully determined by decreasing the pressure stepwise at the intervals of two hours in order to obtain an accurate concentration in equilibrium (see Fig. 1). The conductivities above the $\mathrm{cmc}$ are, therefore, the one of supersaturation under high pressure. In other words, the $\mathrm{cmc}$ values are possible to be determined as a supersaturated $\mathrm{cmc}$ under high pressure. From Fig. 1 pressure is found to function in a inverse fashion to temperature, and there exists the critical solution pressure instead of the micellization temperature (the Krafft point), when a monomeric solubility and $\mathrm{cmc}$ are plotted against pressure ${ }^{13)}$.

The specific conductivity against concentration at a definite pressure can be obtained by cutting the plots in Fig. 1 at a definite pressure (Fig. 2). Fig. 1 includes four typical plots of twelve concentrations. From Fig. 2 the $\mathrm{cmc}$ can be determined as the concentration at a break point, and the $\mathrm{cmc}$ dependence on pressure is given in Fig. 3, where the phase diagram is shown, including monomeric solubility. The critical solution pressure of $\mathrm{C}_{2} \mathrm{BP}\left(\mathrm{C}_{14}\right)_{2}$ is $44 \mathrm{MP}$ at $40.0^{\circ} \mathrm{C}$ from the phase diagram.

Two other examples of pressure dependencies of the specific conductivities are shown in Figs. 4 and 5 for $\mathrm{C}_{4} \mathrm{BP}\left(\mathrm{C}_{14}\right)_{2}$ and $\mathrm{C}_{8} \mathrm{BP}\left(\mathrm{C}_{14}\right)_{2}$, respectively. By the same procedure as mentioned above, the pressure dependence of $\mathrm{cmc}$ can be obtained (Fig. 6). From the pressure dependencies, it can be easily inferred that the smaller the charge separation is, the larger the volume change on micellization $\left(\Delta V_{\mathrm{m}}\right)$ becomes. This can be certainly verified by applying the following equation to the above $\mathrm{cmc}$ changes :

$$
\Delta V_{\mathrm{m}}=-(1+\beta) R T(\partial \ln \mathrm{cmc} / \partial P)_{T}
$$

The results are given in Fig. 7, where the $\beta$ values used are those obtained in the previous 


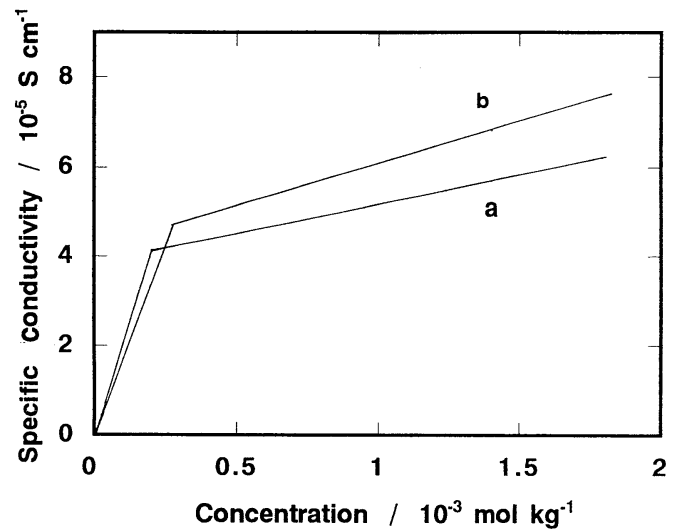

Fig. 2 Relationships between Specific Conductivity and Concentration for $\mathrm{C}_{2} \mathrm{BP}\left(\mathrm{C}_{14}\right)_{2}$ Solution at $40.0^{\circ} \mathrm{C}$ : a $0.1 \mathrm{MP}$, b $150 \mathrm{MP}$.

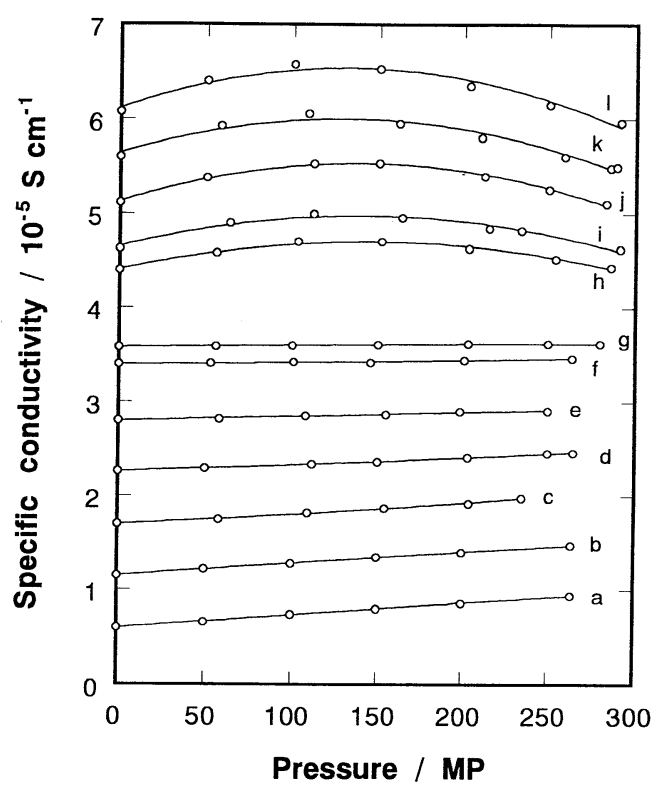

Fig. 4 Relationships between Specific Conductivity and Pressure for $\mathrm{C}_{4} \mathrm{BP}\left(\mathrm{C}_{14}\right)_{2}$ Solution at $40.0^{\circ} \mathrm{C}$ : a 0.0282, b 0.0567, c 0.086 , d 0.113 , e 0.141 , f 0.170 , g 0.18 , h 0.25 , i 0.30 , j $0.40, \mathrm{k} 0.50,10.60 \mathrm{mmol} \mathrm{kg}^{-1}$.

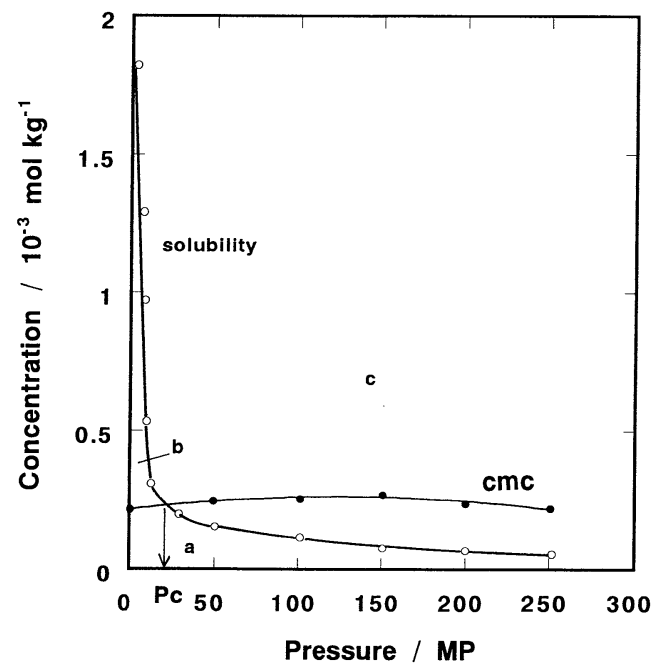

Fig. 3 Phase Diagram of $\mathrm{C}_{2} \mathrm{BP}\left(\mathrm{C}_{14}\right)_{2}$-Water System at $40^{\circ} \mathrm{C}$ with Pressure as Abscissa : a Monomeric Solution, b Micellar Solution, c Hydrated Solid State+Solution, $P_{\mathrm{c}}$, Critical Solution Pressure or Tanaka Pressure ${ }^{14)}$.

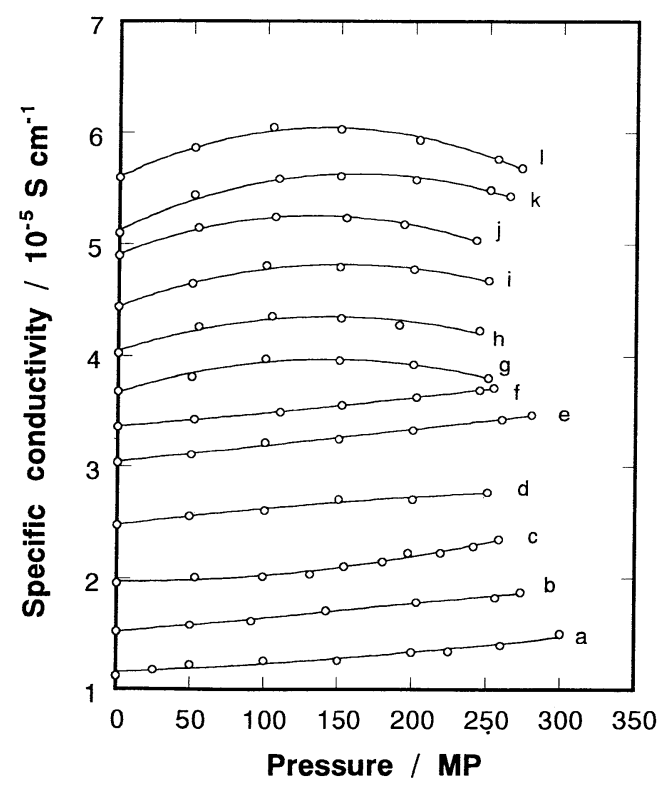

Fig. 5 Relationships between Specific Conductivity and Pressure for $\mathrm{C}_{8} \mathrm{BP}\left(\mathrm{C}_{14}\right)_{2}$ Solution at $40.0^{\circ} \mathrm{C}$ : a $0.024, \mathrm{~b} 0.048, \mathrm{c} 0.072$, d 0.096 , e 0.12 , f 0.145 , g 0.20 , h 0.29 , i 0.40 , j 0.50 , k $0.60,10.70 \mathrm{mmol} \mathrm{kg}^{-1}$. 


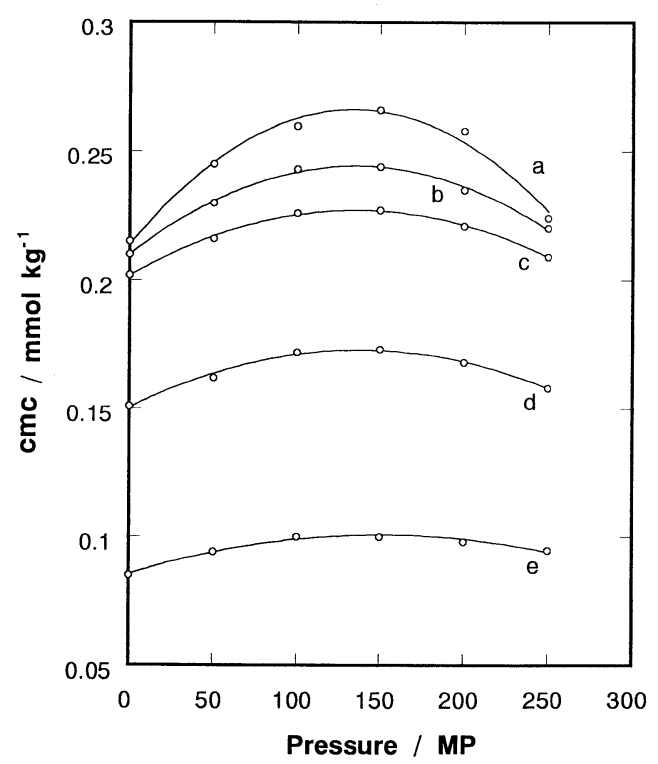

Fig. 6 Pressure Dependence of $\mathrm{cmc}$ : a $\mathrm{C}_{2} \mathrm{BP}\left(\mathrm{C}_{14}\right)_{2}, \mathrm{~b} \mathrm{C}_{4} \mathrm{BP}\left(\mathrm{C}_{14}\right)_{2}, \mathrm{c} \mathrm{C}_{6} \mathrm{BP}\left(\mathrm{C}_{14}\right)_{2}$, $\mathrm{d}_{8} \mathrm{BP}\left(\mathrm{C}_{14}\right)_{2}$, e $\mathrm{C}_{10} \mathrm{BP}\left(\mathrm{C}_{14}\right)_{2}$.

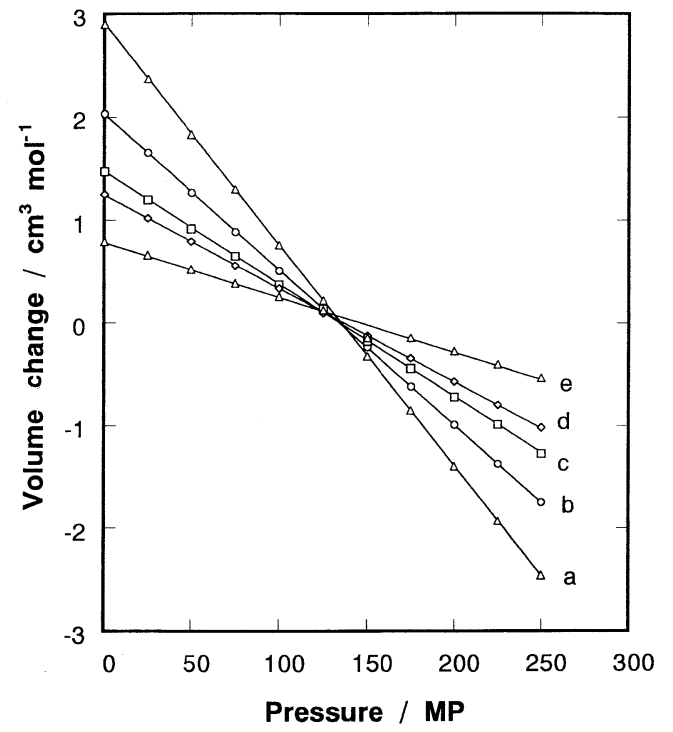

Fig. 7 Pressure Dependence of $\Delta V_{\mathrm{m}}$ : a $\mathrm{C}_{2} \mathrm{BP}\left(\mathrm{C}_{14}\right)_{2}, \mathrm{~b} \mathrm{C}_{4} \mathrm{BP}\left(\mathrm{C}_{14}\right)_{2}, \mathrm{c} \mathrm{C}_{6} \mathrm{BP}\left(\mathrm{C}_{14}\right)_{2}$, d $\mathrm{C}_{8} \mathrm{BP}\left(\mathrm{C}_{14}\right)_{2}$, e $\mathrm{C}_{10} \mathrm{BP}\left(\mathrm{C}_{14}\right)_{2}$.

paper ${ }^{5}$. From the figure it becomes apparent that the $\mathrm{cmc}$ of every surfactant goes through a maximum around the same pressure of $140 \mathrm{PM}$, where the $\mathrm{cmc}$ curves are analyzed by the second order curve. In the preceding paper ${ }^{5}$, the aggregation number of the micelles with respect to the sulfonate ion goes down with increasing charge separation of the counterions at the atmospheric pressure : 74.2, 54.4, 44.1, 33.8, and 33.4 for $\mathrm{C}_{2} \mathrm{BP}, \mathrm{C}_{4} \mathrm{BP}, \mathrm{C}_{6} \mathrm{BP}, \mathrm{C}_{8} \mathrm{BP}$, and $\mathrm{C}_{10} \mathrm{BP}$, respectively. Liquid hydrocarbon is also known to be more compressible than water ${ }^{15)}$. It can be easily understood from the above two facts that the larger micelle with shorter counterions is more compressible than the one of the longer ones. In other words, a larger liquid hydrocarbon portion of inner micelle made of tailes of the sulfonate anions is easily compressed or becomes comparatively smaller in volume with increasing pressure.

Finally, the size change of micelles is discussed from their dependence upon the charge separation of the counterions, where the hydrodynamic radius of micelles are employed as for the size. In Fig. 8 the concentration dependencies of the hydrodynamic radius are shown. Concentration dependence of the radius is relatively small except $\mathrm{C}_{2} \mathrm{BP}\left(\mathrm{C}_{14}\right)_{2}$, while the $\mathrm{C}_{2} \mathrm{BP}\left(\mathrm{C}_{14}\right)_{2}$ micelle becomes more compact due to increasing counterion concentration above the $\mathrm{cmc}^{16)}$. Anyhow, there exits such the definite evidence that the hydrodynamic radius of $\mathrm{C}_{2} \mathrm{BP}\left(\mathrm{C}_{14}\right)_{2}$ micelle is governed by the chain length of tetradecane-1-sulfonate ion, while the others' are controlled mainly by the counterions. The former length, $2.0 \sim 2.2 \mathrm{~nm}$, is quite reasonable, judging from a molecular length of tetradecane-1-sulfonate anion, $1.76 \mathrm{~nm}$ from the CPK atomic model, while the latter radius, $1.2 \sim 1.4 \mathrm{~nm}$, is much shorter than the molecular length of the sulfonate anion. However, this shorter radius, $1.2 \mathrm{~nm}$ especially for $\mathrm{C}_{10} \mathrm{BP}\left(\mathrm{C}_{14}\right)_{2}$ micelle, can be surely understood by the assumption that the radium is controlled by a length of the longer counterion, $\mathrm{C}_{10} \mathrm{BP}$ anion whose molecular length is $2.09 \mathrm{~nm}$. As for the other micelles, the radius is controlled by the combination of the surfactant anion and the divalent counterions, although the counterions are playing more important role, making the micellar structures less condensed. At the same time, the hydrocarbon tails of surfactant ions and the alkanediyl groups of counterions are contacting one another in the 


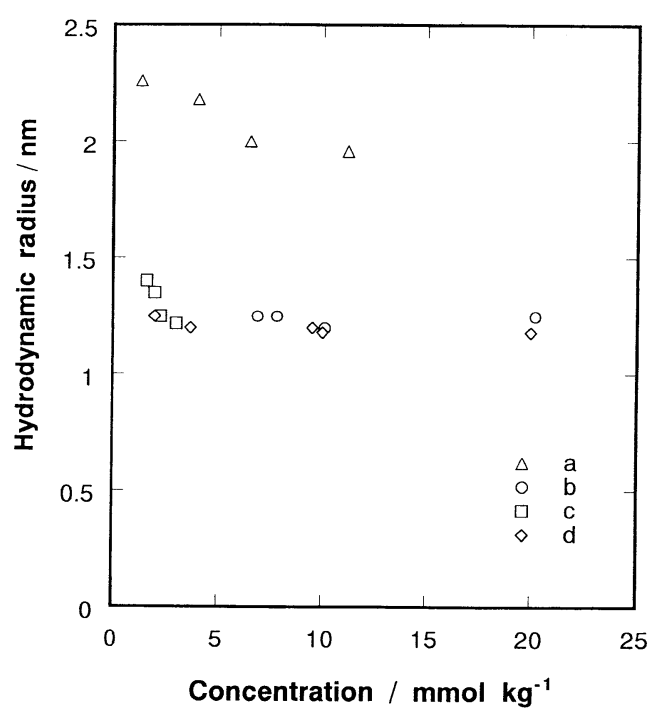

Fig. 8 Concentration Dependence of Hydrodynamic Radius :

a $\mathrm{C}_{2} \mathrm{BP}\left(\mathrm{C}_{14}\right)_{2}, \mathrm{~b} \mathrm{C}_{6} \mathrm{BP}\left(\mathrm{C}_{14}\right)_{2}, \mathrm{c} \mathrm{C}_{8} \mathrm{BP}\left(\mathrm{C}_{14}\right)_{2}, \mathrm{~d} \mathrm{C}_{10} \mathrm{BP}\left(\mathrm{C}_{14}\right)_{2}$.

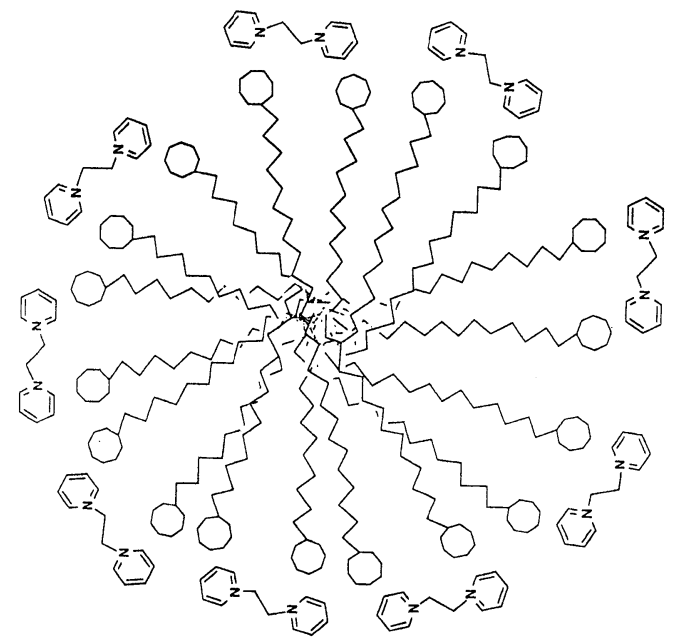

$\mathbf{a}$

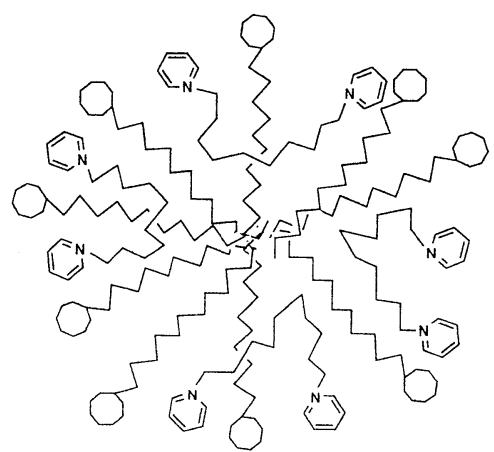

b

Fig. 9 Schematic Illustrations of Micelles of $\mathrm{C}_{2} \mathrm{BP}\left(\mathrm{C}_{14}\right)_{2}$ Micelle (a) and Other Micelles (b).

inner micelles (Fig. 9).

(Received Jan. 24, 1996 ; Accepted March 14, 1996)

\section{References}

1) M. Almgren, S. Swarup, J. Phys. Chem., 87, 876 (1983).

2) A.L. Underwood, E.W. Anacker, J. Phys. Chem., 88, 2390 (1984).

3) Y. Moroi, R. Sugii, C. Akine, R. Matuura, J. Colloid Interface Sci., 108, 180 (1985).

4) Y. Moroi, R. Matuura, T. Kuwamura, S. Inokuma, J. Colloid Interface Sci., 113, 225 (1986). 
5) Y. Moroi, R. Matuura, M. Tanaka, Y. Murata, T. Kuwamura et al., J. Phys. Chem., 94,842 (1990).

6) Y. Moroi, R. Matuura, M. Tanaka et al,, J. Phys. Chem., 96, 8610 (1992).

7) Y. Moroi, Y. Kai, Y. Murata, M. Tanaka, J. Jpn. Oil Chem. Soc., in press.

8) R.F. Tuddenham, A.E. Alexander, J. Phys. Chem., 66, 1839 (1962).

9) S. Kaneshina, M. Tanaka, T. Tomida, R. Matuura, J. Colloid Interface Sci., 48, 450 (1974).

10) N. Nishikido, M. Shinozaki, G. Sugihara, M. Tanaka, S. Kaneshina, J. Colloid Interface Sci., 74, 474 (1980).

11) N. Nishikido, H. Kobayashi, and M. Tanaka, J. Phys. Chem., 86, 3170 (1982).

12) K.E. Bett, J.B. Cappi, Nature, 207, 620 (1965).

13) Y. Moroi, "Micelles : Theoretical and Applied Aspects", Plenum Press, New York (1992), Chapt. 4.

14) E. Kissa, "Fluorinated Surfactants : Synthesis, Properties, Application" Marcel Dekker, Inc., New York-Barsel-Hongkong (1994), Chapt. 6.

15) Chem. Soc. Jpn., “Kagaku Benran, Kisohen”, 4th edition, Maruzen, Tokyo (1993), Section 5.

16) Y. Moroi, J. Colloid Interface Sci., 122, 308 (1988). 


\section{日本油化学会誌本号掲載 論文要旨}

[総説] $\mathrm{CH} / \pi$ 相互作用一その化学・生命科学とのかかわり一

\begin{tabular}{|c|c|c|}
\hline$* 1$ & 明治製菓(株)薬品開発本部 & （元104 東京都中央区京橋2-4-16） \\
\hline$* 2$ & 財団法人微生物化学研究会 & （F141 東京都品川区上大䗁3-14-23） \\
\hline *3 & 横浜国立大学工学部 & 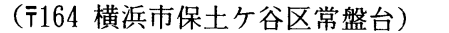 \\
\hline
\end{tabular}

$\mathrm{C} \mathrm{H} / \pi$ 相互作用はソフトな酸（ $\mathrm{C} \mathrm{H}$ ) とソフトな塩基（ $\pi$ 電子系）の間に働く弱い水素結合的な力である。こ の結合力の存在は，X線結晶解析，I R, NMR， C D (円二色性）スペクトルや, これらの組合わせによる実験 手法で証明された。分子軌道法計算もその結論を支持する。C Hにせよ $\pi$ 系にせよ，化学構造の中に一定の対称性 をもって存在するのが一般であるため, $\mathrm{C} \mathrm{H} / \pi$ 結合力は多重に働くうえ相互作用のチャンスが大きい。有機化 合物の立体配座やクロマトグラフィーにおける分離効率, タンパク質の高次構造の中にこの親和力が働いているこ とが分かった。最後に，上の考察をふまえ，この概念の生命科学，物質科学における含意についてふれた。

(連絡者:西尾元宏) Vo1. 45, No. 7, 609 (1996).

[報文]2次計画法による食用油脂の混合率推定

山本 博道 $* 1$ - 山崎惠 - 長尾昭彦 - 石間 紀男 $* 2$

農林水産省食品総合研究所

*1 現在 農林水産省農業環境技術研究所

*2 現在 農林水産省北陸農業試験場
（テ305 茨城県つくば市観音台2-1-2）

（テ305 茨城県つくば市観音台3-1-1）

（敄43-01 新潟県上越市稲田 1-2-1）

混合油脂の脂肪酸組成データから 2 次計画法により混合率を推定する方法を開発した。ごま油, 大豆油, なたね 油, 米ぬか油の混合物にこの方法を適用した。混合に用いられた純粋油の脂肪酸組成が既知である場合は高精度で の推定が可能である。推定誤差の主な原因は各純粋油内の脂肪酸組成の原料による変動である。混合率推定値の分 布範囲を求め,この方法の有効性を確認した。 （連絡者:山本博道）Vol. 45, No. 7, 619 (1996).

\section{[報文] 2価の荷電分離型陽イオンを対イオンにもつ 1 ーテトラデカンスルホン酸塩のミセル形成 に友ほす生効果 \\ 師井義清 $*$ - 川畸聰 - 甲斐禎章・ \\ 村田義夫 · 田中満 \\ * 九州大学理学部化学教室 （T812-81 福岡市東区箱崎 6-10-1） \\ 福岡大学理学部化学教室（F814-80 福岡市城南区七隅 8-19-1）}

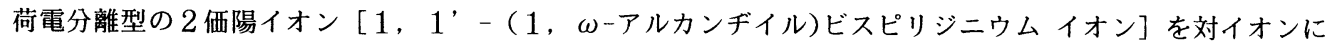

$$
\left\langle\mathrm{N}+-\left(\mathrm{CH}_{2}\right)_{n-+} \bigcirc\left(\mathrm{C}_{14} \mathrm{H}_{29} \mathrm{SO}_{3}\right)_{2}: n=2,4,6,8,10\right.
$$

もつ種々の 1 -テトラデカンスルホン酸塩の溶液物性に及ぼす圧力効果を, それらのミセル形成臨界濃度 ( c m c ) 及び水への溶解度から検討した。 c m c 以下では界面活性剂水溶液の電導度は圧力の増加と共に単調に増大した。 これは，長鎖の活性剂イオンが 2 価の対イオンと c m c 以下でも会合状態にあり，圧力の増加と共にこの会合が減 少していることを示唆している。また, 通常のイオン性界面活性剤と同様にこれらの活性剤の c m c は $140 \mathrm{MP}$ 
付近で極大をもつことも判明した。 $\mathrm{cm} \mathrm{c}$ の圧力依存性からミセル化の体積変化（ $\Delta \nu_{\mathrm{m}}$ ）を評価したところ, 対 イオンの荷電分離が小さいほど $\Delta \nu_{m}$ の值は急激に減少した。ミセル溶液の動的光散乱測定から, ミセルの動的半 径は荷電分離が増すと共にボラホルム型の対イオンに支配されていることも明らかになった。

（連絡者:師井義清）Vol. 45, No. 7, 627（1996）.

\title{
[報文]硫酸ドデシルナトリウム水溶液に上る
}

\section{二成分混合香料の可溶化}

徳 岡由 一 $* 1$, 阿部 正彦 $* 2$

*1 東京理科大学理工学部工業化学科（テ278 千葉県野田市山崎2641）

*2 東京理科大学界面科学研究所（广161 東京都新宿区神楽坂1-3）

現住所 エステー化学株式会社研究部（†161 東京都新宿区下落合1-4-10）

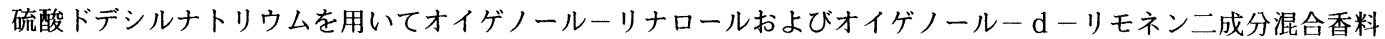
の可溶化を行い, 可溶化能（S C ）に対する香料の混合効果について検討した。オイゲノールーリナロール混合系 における各香料の S C は理想状態に打けるS C とほぼ一致することが明らかとなった。一方，オイゲノールー d リモネン混合系における S C は, 理想状態における S C と異なり, 著しく正にずれた。以上の結果は香料の可溶化 に伴うミセル構造（特にミセル粒子径）の変化およびミセル中における香料の可溶化位置の違いに起因すると考え られる。 (連絡者:徳岡由一) Vol. 45, No. 7, 635 (1996).

\section{[報文] 日本应个チイ(Taxus cuspidata)果寻のレトロ} タイプカロテノイド棈造と酸仳防作用

\author{
眞 岡 孝 至 $* 1$ - 伊 藤 義 博 $* 1$ - 藤原靖 弘 $* 2$ - 橋本圭二 $* 2$ \\ *1（財)生産開発科学研究所（兵606 京都市左京区下鴨森本町15） \\ *2 京都薬科大学 （开607 京都市山科区御陵中内町1）
}

イチイ（Taxus cuspidata）種子に含まれるレトロタイプカロテノイドの構造とそれらの酸化防止活性について 検討した。3種のレトロタイプカロテノイド，ロドキサンチン（１），エショルツキサントン（２）およびエ ショルツキサンチン（３）を分離, 同定した。さらに ${ }^{1} \mathrm{H}-\mathrm{NMR}$ およびC D スペクトルより 2 の立体化学を 明らかにした。これらのカロテノイドは $\beta$ 一カロテンより強力なフリーラジカルおよび一重項酸素に対する酸化防 止活性を示した。

（連絡者:眞岡孝至）Vol. 45, No. 7, 641（1996）.

\section{[報文] リン脂暂のスメクチック㖡晶状椇 の界面化学的性第 1 報) \\ シシミリストイノレホスファチシシルレコリン}

洨晶二行子膜の定厓熱容是と高次相転移現象

田 嶋 和 夫*1 - 今井洋 子*1 - N. L. GERSHFELD*2

*1 神奈川大学工学部化学教室（₹221 横浜市神奈川区六角橋3-27）

*2 Nationa1 Institutes of Health, Bethesda, Md., 20812 U. S. A.

高感度 $\left(5 \times 10^{-5} \mathrm{~J} / \mathrm{d} \mathrm{e} \mathrm{g・c} \mathrm{m}{ }^{3}\right)$ の熱伝導型熱量計を用いて, 水に分散したジミリストイルホスファチジル コリン ( D M P C )の定圧比熱容量 $\left(\mathrm{C}_{\mathrm{pL}}\right)$ を $25^{\circ} \mathrm{C}$ と $35^{\circ} \mathrm{C}$ 範囲で測定した。その結果, $28.60{ }^{\circ} \mathrm{C}$ と 29.50 ${ }^{\circ} \mathrm{C}$ 間で $\mathrm{C}_{\mathrm{p} L}$ に異常性が現れた。すなわち, $\mathrm{C}_{\mathrm{p} \mathrm{L}} \sim \mathrm{T}$ 曲線は最初減少し, $28.96{ }^{\circ} \mathrm{C}$ で変曲点を経た後, 平坦な 変化となった。 $28.96{ }^{\circ} \mathrm{C}$ の変曲点はDMP C二分子膜が中間相(Intermediary phase)を通して高次の相転移 